\title{
Aktivitas Antibakteri Ekstrak Etil Asetat Jahe Merah (Zingiber officinale Roscoe var. sunti) Terhadap Bakteri Staphylococcus aureus dan Escherichia coli
}

\author{
Sari Purbaya*, Lilis Siti Aisyah, Jasmansyah, Wenny Eliza Arianti \\ Jurusan Kimia, Fakultas Sains dan Informatika, Universitas Jenderal Achmad Yani \\ Jalan Terusan Jendral Sudirman, Cimahi, Jawa Barat, 40285 \\ *E-mail: saripurbaya@gmail.com
}

\begin{abstract}
Abstrak
Rimpang jahe merah (Zingiber officinale Roscoe var. sunti) salah satu herbal yang banyak dimanfaatkan sebagai obat tradisional. Penelitian kali ini adalah untuk mengetahui metabolit sekunder yang terkandung didalam tanaman rimpang jahe merah dan aktivitas antibakteri terhadap bakteri Staphylococcus aureus dan Escherichia coli. Sebanyak 483,2 gram serbuk jahe merah diekstraksi dengan metode maserasi didapatkan ekstrak etil asetat 15,85 g. Uji aktivitas antibakteri ekstrak jahe merah terhadap bakteri $S$. aureus dan E. coli menggunakan metode mikrodilusi menunjukkan ekstrak etil asetat dapat menghambat pertumbuhan S. aureus dengan MIC (Minimum Inhibitory Concentration) 6,3\% dan MBC (Minimum Bactericidal Concentration) 25\% dan ekstrak etil asetat rimpang jahe merah dapat MIC (Minimum Inhibitory Concentration) E. coli dengan konsentrasi hambat minimum $25 \%$ dan MBC (Minimum Bactericidal Concentration) 50\%. Hasil menunjukkan bahwa ekstrak etil asetat rimpang jahe merah paling berpengaruh dan lebih berpotensi dalam menghambat pertumbuhan bakteri Gram positif dibandingkan dengan penghambatan terhadap Gram negatif.
\end{abstract}

Kata Kunci : Antibakteri, E.coli, Jahe Merah (Z. officinale Roscoe var. sunti), S. aureus

\begin{abstract}
Red ginger rhizome (Zingiber officinale Roscoe var. Sunti) is one of the herbs that is widely used as traditional medicine. The present study was to determine the secondary metabolites contained in red ginger rhizome plants and antibacterial activity against Staphylococcus aureus and Escherichia coli bacteria. A total of 483.2 grams of red ginger powder was extracted by maceration method obtained from ethyl acetate extract $15.85 \mathrm{~g}$. Antibacterial activity of red ginger extract against $S$. aureus and $E$. coli using microdilution method showed that ethyl acetate extract could inhibit S. aureus growth by MIC (Minimum Inhibitory Concentration) 6.3\% and MBC (Minimum Bactericidal Concentration) 25\% and extract Ethyl acetate red ginger rhizome can Minimum MIC (E. Inhibition Concentration) E. coli with a minimum inhibitory concentration of $25 \%$ and MBC (Minimum Bactericidal Concentration) $50 \%$. The results showed that the red ginger rhizome ethyl acetate extract was the most influential and had more potential to inhibit the growth of Gram positive bacteria compared to inhibition of Gram negative.
\end{abstract}

Keywords: Antibacterial, E.coli, Red Ginger (Z. officinale Roscoe var. Sunti), S. aureus

\section{PENDAHULUAN}

Penyakit infeksi merupakan penyakit yang sering terjadi. Penyakit ini paling banyak diderita oleh penduduk di negara berkembang, termasuk Indonesia. Salah satu penyakit infeksi yang menyerang sebagian besar penduduk Indonesia adalah diare. Diare dan gastroenteritis menjadi penyakit dengan urutan pertama yang menyebabkan pasien rawat inap dirumah sakit sakit [5].
Pencegahan dan pengobatan penyakit infeksi selain menggunakan bahan-bahan kimia, juga dilakukan dengan menggunakan bahan-bahan alam sebagai obat tradisional dari ekstrak tanaman. Salah satu tanaman herbal yang banyak dimanfaatkan sebagai obat tradisional adalah jahe.

Rimpang jahe mengandung senyawa antimikroba golongan fenol, flavonoid, terpenoid dan minyak atsiri yang terdapat pada ekstrak jahe merupakan golongan senyawa bioaktif yang dapat menghambat pertumbuhan mikroba [7]. 


\section{METODOLOGI PENELITIAN}

\subsection{Alat}

Alat gelas laboratorium, bunsen, blender merk Philips, rotary evaporator merk Heidolph Laborata 4000 type Heizbad WB, kertas pembungkus, inkubator merk ESCO type CelMate ${ }^{\circledR} \mathrm{CO}_{2}$, mikropipet Acura 815 Socorex, oven merk Memmert, pisau, satu set alat maserasi, spidol, batang pengaduk, ose, spirtus, tip kuning, kertas timbang, cawan petri, pinset, mikrotiter plat, dan objek glass.

\subsection{Bahan}

Jahe merah (Z. officinale Roscoe var. sunti), aquades, antibiotik ciprofloxaxin, biakan murni E.coli, biakan murni S. Aureus, dimetil sulfoksida (DMSO), medium mueller hinton agar (MHA), medium mueller hinton broth (MHB), mac conkey agar, metanol $\left(\mathrm{CH}_{3} \mathrm{OH}\right)$ redest, natrium klorida $(\mathrm{NaCl}) 0,9 \%$, barium klorida $(\mathrm{BaCl}) 1 \%$, asam sulfat $\left(\mathrm{H}_{2} \mathrm{SO}_{4}\right) 1 \%$, etilasetat $\left(\mathrm{CH}_{3} \mathrm{COOC}_{2} \mathrm{H}_{5}\right)$ redest dan pelat $\mathrm{KLT}$.

\subsection{Prosedur Penelitian}

\subsubsection{Persiapan sampel dan ekstraksi rimpang jahe merah}

Jahe merah yang telah halus dimaserasi dengan pelarut $n$ - heksan. Ekstraksi dilakukan hingga larutan tidak berwarna lagi, kemudian dilanjutkan dengan proses penyaringan. Setelah disaring, pelarut diuapkan dengan rotary evaporator sehingga diperoleh ekstrak kental. Residu dari ekstrak yang tidak tersaring kemudian dimaserasi dengan pelarut etilasetat. Ekstrak kental etilasetat yang dihasilkan selanjutnya dilakukan uji fitokimia.

\section{1) Uji Fitokimia}

Uji fitokimia yang dilakukan pada masingmasing ekstrak kental meliputi uji alkaloid, uji flavonoid, uji terpenoid, uji tanin dan uji saponin.

\section{2) Uji alkaloid}

Ke dalam $1 \mathrm{~mL}$ ekstrak teteskan 1-2 tetes pereaksi Meyer. Alkaloid positif jika terjadi endapan kuning muda.

\section{3) Uji flavonoid}

Ke dalam $5 \mathrm{~mL}$ ekstrak tambahkan serbuk $\mathrm{Mg}, 2 \mathrm{~mL}$ larutan alkohol - $\mathrm{HCl}$ (1:1) dan $5 \mathrm{~mL}$ larutan amil alkohol. Kocok dan amati perubahan warnanya. Jika timbul warna merah, kuning atau jingga pada lapisan amil alkohol maka positif ada flavonoid.

\section{4) Uji terpenoid/steroid}

Kedalam 1-2 mL ekstrak pada tabung reaksi ditambahkan 2 tetes Anhidrida asetat dan diaduk. Kemudian teteskan 1-2 tetes $\mathrm{H}_{2} \mathrm{SO}_{4}$ pekat dan amati warna yang terbentuk. Catat warna yang terbentuk pada saat diteteskan dan warna setelah beberapa saat. Uji ini positif bila terjadi perubahan warna merah ke hijau ke ungu ke biru.

\section{5) $\underline{\text { Uji tanin }}$}

Sejumlah ekstrak pada lempeng porselin ditambahkan beberapa tetes larutan $\mathrm{FeCl}_{3} 1 \%$. Golongan tanin positif jika terjadi perubahan warna menjadi hjau ungu atau hitam.

\section{6) Uji saponin}

Sebanyak $10 \mathrm{~mL}$ ekstrak dimasukkan kedalam tabung reaksi dikocok vertikal selama 10 detik, jika terbentuk busa $1-10 \mathrm{~cm}$ stabil selama 10 menit maka saponin positif. Selanjutnya tambahkan 1 tetes larutan HCL 2N, saponin positif jika busa tidak hilang.

\subsubsection{Uji Aktivitas Antibakteri}

\section{1) Penentuan Konsentrasi Hambat Minimum} (KHM) dengan metode dilusi cair (mikrodilusi)

Disiapkan mikrotiter plat 96 lubang. Pada kolom 1 dimasukkan kontrol positif sebanyak 50 $\mu \mathrm{L}$ antibiotik ciprofloxaxin dan $50 \mu \mathrm{L}$ bakteri, sedangkan pada kolom 2 dimasukkan kontrol negatif sebanyak $50 \mu \mathrm{L}$ MHB dan $50 \mu \mathrm{L}$ bakteri. Pada kolom no 3-12 diisi dengan 50 $\mu \mathrm{L}$ campuran media MHB dan $50 \mu \mathrm{L}$ bakteri. Pada kolom no 3 diisi dengan $100 \mu \mathrm{L}$ ekstrak jahe merah kemudian dihomogenkan. Dari kolom no.3 diambil $100 \mu \mathrm{L}$ dimasukkan ke kolom no.4 kemudian dihomogenkan, dan seterusnya sampai kolom no.12, dari kolom no.12 diambil $100 \mu \mathrm{L}$ kemudian dibuang. Pengujian dilakukan sebanyak 2 perlakuan. Mikrotiter plat diinkubasi pada suhu $37^{0} \mathrm{C}$ selama 18-24 jam. Dilihat apakah terdapat endapan/tidak atau dilihat kekeruhan pada setiap sumur. Bening pertama pada tiap baris menunjukkan nilai MIC (Minimum Inhibitory Concentration).

\section{2) Penentuan MBC (Minimum Bactericidal Concentration)}


Dilakukan pemindah tanaman dari masingmasing kolom sampel uji yang tidak memperlihatkan adanya pertumbuhan mikroba pada uji MBC sebanyak 1 ose, kemudian diinokulasikan ke cawan petri yang sudah berisi media MHA. Diinkubasi pada suhu $37^{\circ} \mathrm{C}$ selama 18-24 jam. Dilihat apakah terjadi pertumbuhan bakteri atau tidak. Tidak adanya pertumbuhan bakteri menunjukkan nilai konsentrasi bunuh minimum atau MBC.

\section{HASIL DAN PEMBAHASAN}

\subsection{Hasil penelitian}

\subsubsection{Hasil Determinasi}

Determinasi tumbuhan dilakukan di Laboratorium Herbarium Sekolah Ilmu dan Teknologi Hayati ITB yang menyatakan bahwa tanaman yang digunakan pada penelitian ini adalah jahe merah (Z. officinale Roscoe var. sunti).

\subsubsection{Hasil Ekstraksi}

Dari hasil preparasi sampel rimpang jahe merah basah sebanyak $4 \mathrm{~kg}$ diperoleh serbuk rimpang jahe merah sebanyak 483,2 g. Ekstrak etilasetat $15,85 \mathrm{~g}$.

\subsubsection{Uji Fitokimia}

Hasil uji fitokimia ekstrak etil asetat positif mengandung alkaloid, flavonoid dan terpenoid.

\subsubsection{Uji Aktivitas Antibakteri}

Hasil uji aktivitas antibakteri yaitu berupa konsentrasi hambat minimum dan konsentrasi bunuh minimum dari ekstrak jahe merah terhadap pertumbuhan bakteri S. aureus dan E. coli diperlihatkan pada Tabel 1-4.

Tabel 1. Hasil Pengamatan Konsentrasi Hambat Minimum Ekstrak Jahe Merah terhadap pertumbuhan bakteri $S$. aureus

\begin{tabular}{|c|c|c|c|c|c|c|c|c|c|c|c|c|}
\hline \multirow{2}{*}{$\begin{array}{c}\text { Ekstrak } \\
\text { Jahe Merah }\end{array}$} & \multirow{2}{*}{$\begin{array}{l}\mathrm{K} \\
(+)\end{array}$} & \multirow{2}{*}{$\begin{array}{l}\mathrm{K} \\
(-)\end{array}$} & \multicolumn{10}{|c|}{ Pengenceran ekstrak jahe merah (\%) } \\
\hline & & & 100 & 50 & 25 & 12,5 & 6,3 & 3,1 & 1,5 & 0,8 & 0,4 & 0,2 \\
\hline \multirow{2}{*}{$\begin{array}{c}\text { Fraksi etil } \\
\text { asetat }\end{array}$} & + & - & + & + & + & + & + & - & - & - & - & - \\
\hline & + & - & + & + & + & + & + & - & - & - & - & - \\
\hline
\end{tabular}

Keterangan : (+) tidak terbentuk endapan/tidak ada pertumbuhan bakteri

(-) terbentuk endapan/ada pertumbuhan bakteri

Tabel 2. Hasil Pengamatan Konsentrasi Bunuh Minimum Ekstrak Jahe Merah terhadap pertumbuhan bakteri $S$. aureus

\begin{tabular}{|c|c|c|c|c|c|}
\hline \multirow{2}{*}{ Ekstrak Jahe Merah } & \multicolumn{5}{|c|}{ Pengenceran ekstrak jahe merah (\%) } \\
\cline { 2 - 6 } & 100 & 50 & 25 & 12,5 & 6,3 \\
\hline Fraksi etil asetat & + & + & + & - & - \\
\hline
\end{tabular}

Keterangan : (+) membunuh bakteri (-) tidak membunuh bakteri

Tabel 3. Hasil Pengamatan Konsentrasi Hambat Minimum Ekstrak Jahe Merah terhadap pertumbuhan bakteri E.coli

\begin{tabular}{|c|c|c|c|c|c|c|c|c|c|c|c|c|}
\hline \multirow{2}{*}{$\begin{array}{c}\text { Ekstrak } \\
\text { Jahe Merah }\end{array}$} & \multirow{2}{*}{$\begin{array}{c}\mathrm{K} \\
(+)\end{array}$} & \multirow{2}{*}{$\begin{array}{l}\mathrm{K} \\
(-)\end{array}$} & \multicolumn{10}{|c|}{ Pengenceran ekstrak jahe merah $(\%)$} \\
\hline & & & 100 & 50 & 25 & 12,5 & 6,3 & 3,1 & 1,5 & 0,8 & 0,4 & 0,2 \\
\hline \multirow{2}{*}{$\begin{array}{c}\text { Fraksi etil } \\
\text { asetat }\end{array}$} & + & - & + & + & + & - & - & - & - & - & - & - \\
\hline & + & - & + & + & + & - & - & - & - & - & - & - \\
\hline
\end{tabular}

Keterangan : (+) tidak terbentuk endapan/tidak ada pertumbuhan bakteri

(-) terbentuk endapan/ada pertumbuhan bakteri

Tabel 4. Hasil Pengamatan Konsentrasi Bunuh Minimum Ekstrak Jahe Merah terhadap pertumbuhan bakteri E. coli

\begin{tabular}{|c|c|c|c|c|c|}
\hline \multirow{2}{*}{ Ekstrak Jahe Merah } & \multicolumn{5}{|c|}{ Pengenceran ekstrak jahe merah (\%) } \\
\cline { 2 - 6 } & 100 & 50 & 25 & 12,5 & 6,3 \\
\hline Fraksi etil asetat & + & + & - & - & - \\
\hline
\end{tabular}

Keterangan : (+) membunuh bakteri (-) tidak membunuh bakteri 


\subsection{Pembahasan}

Proses pembuatan ekstrak rimpang jahe merah diperoleh dengan metode maserasi. Pada metode ini digunakan pelarut etil asetat. Hal ini bertujuan untuk memperoleh jenis ekstrak dengan kandungan senyawa yang lebih spesifik. Hasil menunjukkan bahwa ekstrak etilasetat positif mengandung terpenoid, flavonoid dan alkaloid.

Fraksi ekstrak etil asetat dan metanol jahe merah mengandung senyawa alkaloid. Alkaloid pada tumbuhan umumnya berbentuk garam, yakni berikatan dengan asam-asam organik yang terdapat dalam tumbuhan, seperti asam suksinat, maleat, mekonat, kinar dan bersifat larut dalam pelarut polar [3]. Menurut Purba [9] alkaloid mengandung nitrogen sebagai bagian dari sistem sikliknya serta mengandung substituen yang bervariasi seperti gugus amina, amida, fenol dan metoksi sehingga alkaloid bersifat semipolar ke polar. Pada pengujian alkaloid [6] hasil positif akan terbentuk endapan putih kekuningan pada penambahan pereaksi Mayer. Persamaan reaksi Mayer ditunjukkan oleh Gambar 1.

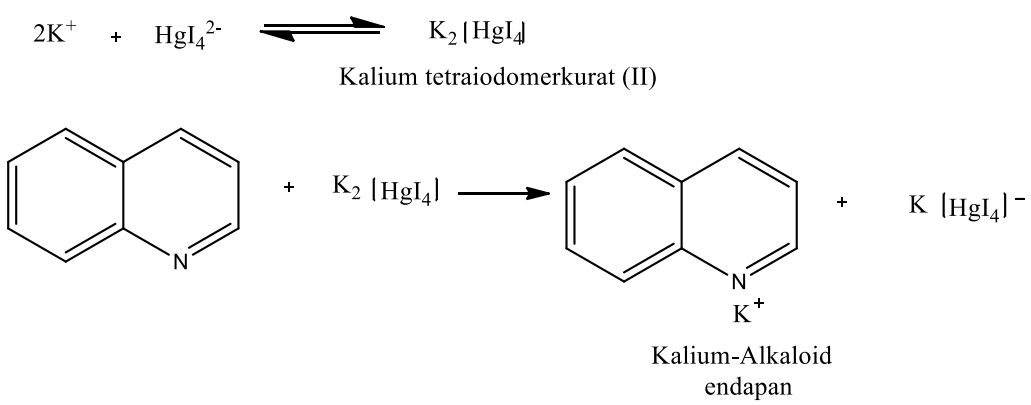

Gambar 1. Reaksi pembentukan Kalium-Alkaloid (endapan) dengan pereaksi mayer [11]<smiles>CC(C)[C@H](C)[C@H](C)C(C)C</smiles>

Flavonol<smiles>O=c1oc2ccccc2c(O)c1O</smiles>

$\sqrt{1}$<smiles>CC(C)C</smiles><smiles></smiles>

Gambar 2. Reaksi pembentukan garam flavilium [6]

Identifikasi flavonoid menunjukkan hasil yang positif pada fraksi etilasetat yaitu terbentuk lapisan kuning atau orange setelah ditambahkan $\mathrm{HCl}$ pekat dan logam $\mathrm{Mg}$ disebabkan karena terbentuknya garam flavilium. Adapun mekanisme reaksi pembentukan garam flavilium diperlihatkan pada Gambar 2. Flavonoid umumnya lebih mudah larut dalam pelarut polar dikarenakan memiliki ikatan dengan gugus gula 
[12]. Fraksi etilasetat tidak menunjukkan hasil positif terhadap pengujian saponin dan tanin.

Hasil pewarnaan dapat dilihat pada yang menunjukkan preparat bakteri S.aureus termasuk kelompok bakteri Gram positif. sedangkan preparat bakteri E.coli merupakan bakteri Gram negatif. Dinyatakan bahwa perbedaan struktur dinding sel bakteri Gram positif dan Gram negatif menyebabkan perbedaan reaksi dalam permeabilitas zat warna dan penambahan larutan pemucat. Sebagian besar dinding sel bakteri Gram positif terdiri dari peptidoglikan, sedangkan dinding sel bakteri Gram negatif mempunyai kandungan lipid yang tinggi dibandingkan dinding sel bakteri Gram positif. Lipid ini akan larut dalam alkohol yang digunakan sebagai larutan pemucat, sehingga pori-pori dinding sel membesar dan meningkatkan daya larut kompleks kristal violetyodium pada dinding sel bakteri Gram negatif [13].

Pada bakteri Gram positif akan terbentuk persenyawaan kompleks kristal violet yodium ribonukleat yang tidak larut dalam larutan pemucat. Persenyawaan ini tidak terbentuk pada bakteri Gram negatif sehingga diduga adanya perbedaan kandungan asam ribonukleat antara bakteri Gram positif dan Gram negatif. Pemberian larutan mordan atau yang digunakan adalah larutan lugol dimaksudkan untuk meningkatkan afinitas pengikatan zat warna oleh bakteri sehingga pengikatan zat warna oleh bakteri menjadi lebih kuat. Setelah penambahan larutan lugol zat warna akan lebih jelas terlihat dan zat warna lebih sulit dilarutkan. Penambahan zat warna kedua atau safranin tidak menyebabkan perubahan warna pada bakteri Gram positif, karena persenyawaan kompleks kristal violetyodium tetap terikat pada dinding sel. Pada bakteri Gram negatif, penambahan safranin menyebabkan sel bakteri berwarna merah, karena persenyawaan kompleks kristal violet-yodium larut dan dinding sel kemudian mengikat zat warna kedua. Fungsi zat warna safranin hanyalah sebagai pembeda (kontras) terhadap zat warna kristal violet.

Berdasarkan hasil penelitian yang diperoleh, ekstrak etil asetat jahe merah mempunyai sifat antibakteri diduga akibat adanya senyawa metabolit sekunder yang terkandung sehingga dapat membunuh bakteri S.aureus dan E.coli yang ditandai dengan tidak adanya pertumbuhan bakteri yang telah ditambahkan ekstrak etil asetat jahe merah.

Nursal [7] menyatakan bahwa terpenoid dan flavonoid pada jahe merupakan beberapa senyawa aktif yang dapat menghambat pertumbuhan bakteri. Senyawa golongan terpenoid dapat berikatan dengan protein dan lipid yang terdapat pada membran sel dan bahkan dapat menimbulkan lisis pada sel. Rusaknya membran sel bakteri, akan mengganggu proses transport nutrisi, sehingga sel akan mengalami kekurangan nutrisi yang dibutuhkan dalam proses pertumbuhan.

Komponen dinding sel bakteri Gram positif adalah peptidoglikan yang tersusun dari $\mathrm{N}$-asetil glukosamin dan $\mathrm{N}$-asetil asam muramat, yang terikat melalui ikatan $\beta$-1,4-glikosida. Pada Nasetil asam muramat terdapat rantai asam amino pendek yang terdiri dari L-alanin, D-glutamat, asam diaminopimelat, dan D-alanin yang terikat melalui ikatan peptida. Peranan ikatan peptida ini sangat penting dalam menghubungkan antara rantai satu dengan rantai lainnya. Senyawa alkaloid bekerja sebagai antibakteri dengan cara mengganggu komponen penyusun peptidoglikan pada sel bakteri sehingga lapisan dinding sel tidak terbentuk secara utuh, terganggunya sintesis peptidoglikan sehingga pembentukan sel tidak sempurna karena tidak mengandung peptidoglikan dan dinding sel akan lisis [1].

Dinding sel yang telah rusak dapat mengakibatkan senyawa metabolit sekunder masuk lebih dalam dan merusak membran bakteri. Dinding sel yang rusak mengakibatkan senyawa metabolit sekunder dapat masuk lebih dalam dan merusak membran bakteri. Senyawa flavonoid dapat mendenaturasi protein sel bakteri dan dapat merusak membran sitoplasma yang dapat menyebabkan bocornya metabolit penting dan menginaktifkan sistem enzim bakteri. Kerusakan ini memungkinkan nukleotida dan asam amino merembes keluar dan mencegah masuknya bahanbahan aktif ke dalam sel, keadaan ini dapat menyebabkan kematian bakteri. Senyawa flavonoid juga dapat menembus peptidoglikan yang bersifat polar karena flavonoid juga bersifat polar [8]. Senyawa flavonoid memiliki mekanisme membentuk senyawa kompleks protein, antara protein yang dapat larut, protein ekstraseluler, dan dinding sel. Kompleks tersebut menyebabkan terganggunya integritas membran sel bakteri [2].

Pada penentuan Minimum Inhibitory Concentration (MIC) fraksi etilasetat memiliki potensi pada bakteri $S$. aureus pada konsentrasi 6.3\% maupun bakteri E.coli pada konsentrasi 25\%, dan Minimum Bactericidal Concentration (MBC) S. aureus pada konsentrasi 25\% dan E. coli pada konsentrasi $50 \%$.

Pada bakteri $S$. aureus menunjukkan hasil yang lebih baik dibandingkan pada bakteri E.coli. 
Menurut Pelczar \& Chan [8], perbedaan respon ini terjadi akibat perbedaan permukaan luar dari dinding sel yaitu lapisan lipopolisakarida antara bakteri Gram-negatif dan bakteri Gram-positif. Bakteri Gram-positif memiliki dinding sel yang lebih sederhana, dengan jumlah peptidoglikan yang relatif banyak. Dinding sel bakteri Gramnegatif memiliki peptidoglikan yang lebih sedikit dan secara struktural lebih kompleks. Membran bagian luar pada dinding sel Gram-negatif mengandung lipopolisakarida, yaitu karbohidrat yang terikat dengan lipid. Adanya lapisan lipopolisakarida dan membran luar yang lebih kompleks pada bakteri E.coli ini menyebabkan struktur bakteri menjadi lebih kokoh sehingga diduga sulit ditembus oleh senyawa antimikroba dari ekstrak jahe.

\section{Kesimpulan}

Ekstrak etil asetat rimpang jahe merah merah (Z. officinale Roscoe var. sunti) memberikan pengaruh baik sebagai antibakteri terhadap pertumbuhan bakteri $S$. aureus dan E. coli. Ekstrak etil asetat rimpang jahe merah ( $Z$. officinale Roscoe var. sunti) memiliki konsentrasi hambat minimum (KHM) yang sangat berpengaruh yaitu S. aureus pada konsentrasi 6,3\% dan E. coli pada konsentrasi $25 \%$. Ekstrak etil asetat rimpang jahe merah (Z. officinale Roscoe var. sunti) memiliki konsentrasi bunuh minimum (KBM) yaitu $S$. aureus pada konsentrasi $25 \%$ dan E. coli pada konsentrasi 50\%.

\section{Daftar Pustaka}

[1] Cowan, M. M.., 1999. Plant Product as Antimicrobial Agents. Clinical Microbiology Review. 27(2); 181.

[2] Dwidjoseputro, D. 1964. Dasar-dasar Mikrobiologi. Penerbit Djambatan, Malang.

[3] Endang, H. 2015. Analisis fitokimia. EGC. Jakarta.

[4] Harbone, J.B., Phytochemical Methods, diterjemahkan oleh Kosasi Padmawinata dan Iwang Soedio. 1987. Metode Fitokimia:
Penuntun Cara Modern Menganalisis Tumbuhan. Penerbit ITB. Bandung.

[5] Kementrian Kesehatan RI. 2011. Situasi Diare di Indonesia. Jakarta: Kementrian Kesehatan Republik Indonesia. II. pp 1-3. Lay, B.W \& Sugyo H. 1992. Mikrobiologi. Bioteknologi Institut Pertanian Bogor. Jakarta.

[6] Marliana, D.S.,Venty, S., \& Suyono. 2005. Skrining Fitokimia dan Analisis Kromatografi Lapis Tipis Komponen Kimia Buah Labu Siam (Sechium edule Jacq. Swartz.) dalam Ekstrak Etanol. Jurnal Biofarmasi. 3(1):29

[7] Nursal, W., Sri \& Wilda S. 2006. Bioaktifitas ekstrak jahe (Zingiber officinale Roxb.) dalam menghambat pertumbuhan koloni bakteri Escherichia coli dan Bacillus subtilis. Jurnal Biogenesis. 2 (2): 64-66.

[8] Pelczar, M.J. \& Chan, E.C.S. 1998. DasarDasar Mikrobiologi. UI Press. Jakarta.

[9] Purba, R..D. 2001. Analisis Komposisi Alkaloid Daun Handeuleun (Graptophyllum pictum (Linn), Griff) yang Dibudidayakan dengan Taraf Nitrogen yang Berbeda. Skripsi. Bogor:Institut Pertanian Bogor.

[10] Radiati, L.E. 2002. Mekanisme Penghambatan Virulensi Bakteri Entropatogen oleh Ekstrak Rimpang Jahe (Zingiber officinale Roscoe). Disertasi. Pascasarjana, IPB, Bogor.

[11] Setyowati, W, Sri R.T.D.A, Ashadi, Bakti, M \& Cici, P.R. 2014. Skrining Fitokimia dan Identifikasi Komponen Utama Ekstrak Metanol Kulit Durian (Durio zibethinus Murr.) Varietas Petruk. Seminar Nasional Kimia dan Pendidikan Kimia VI. Surakarta.

[12] Markham, K.R., 1988, Cara Mengidentifikasi Flavonoid, diterjemahkan oleh Kosasih Padmawinata, 15, Penerbit ITB, Bandung.

[13] Alhadi, Fatri, Hidayat, R., 2012, Identifikasi Streptococcus Equi dari Kuda yang Diduga Menderita Strangles, Jurnal Imu Pertanian Indonesia (JIPI), Vol. 17, No. 3. 